\title{
Exploring the functional space of thiiranes as gelatinase inhibitors using click chemistry
}

\author{
Sebastian A. Testero, Leticia I. Llarrull, Jed F. Fisher, Mayland Chang, \\ and Shahriar Mobashery* \\ Department of Chemistry and Biochemistry, University of Notre Dame, \\ Notre Dame, IN 46556, USA \\ E-mail: mobashery@nd.edu
}

\section{Dedicated to Professors Rita H. Rossi, Julio C. Podestá, Manuel González Sierra and Oscar S. Giordano}

\begin{abstract}
A series of 4-[(triazolyl)methoxy]phenyl analogs of the phenoxyphenyl-substituted thiirane SB3CT 1 was evaluated for its ability to inhibit gelatinases, members of the matrix metalloproteinase family of enzymes. The triazole segment of these inhibitors was assembled using the Meldal-Sharpless copper-catalyzed Huisgen dipolar cycloaddition of an azide and a terminal alkyne. While these triazole derivatives possessed fair activity as gelatinase inhibitors, an intermediate used in the dipolar cycloaddition, 4-(propargyloxy)phenyl derivative 2, showed very good activity ( $>50 \%$ inhibitory activity following a $3 \mathrm{~h}$ pre-incubation of 2 at a concentration of $3 \mu \mathrm{M}$ ) as an inhibitor of human matrix metalloproteinase- 2 .
\end{abstract}

Keywords: CuAAC click chemistry, thiirane, Gelatinase inhibitor, MMP

\section{Introduction}

The "click" reactions have opened new opportunities in medicinal chemistry for lead optimization as a result of the ability of these reactions to rapidly construct analog libraries. ${ }^{1-4}$ The copper-catalyzed Huisgen 1,3-dipolar cycloaddition of alkynes and azides, yielding 1,4disubstituted 1,2,3-triazoles, is the gold standard of a click reaction. ${ }^{5-8}$

Triazoles possess a number of desirable features in developing the structure-activity correlations used in medicinal chemistry. The aromatic stabilization of the triazole renders the ring stable to reduction, oxidation, and both acid- and base-catalyzed hydrolysis. Accordingly, triazoles are relatively resistant to metabolic degradation. ${ }^{9,10}$ In addition, their high dipole 
moment facilitates formation of hydrogen bond through their nitrogen atoms, as well as their participation in dipole-dipole and $\pi$-stacking interactions with their macromolecular target.

Matrix metalloproteinases (MMPs) belong to a family of closely related zinc-dependent endopeptidases that are implicated in the cleavage of extracellular matrix proteins. MMPs play a crucial role in several pathological and physiological processes such as tissue remodeling, embryonic development and wound healing. ${ }^{11-13}$ As a consequence, a number of disease processes are associated with their misregulation and uncontrolled activities including neurological disorders, arthritis, cardiovascular diseases, and cancer. Given the involvement of the MMPs in these pathologies, MMP-specific inhibitors would be very valuable as therapeutic agents. $^{14}$

We have previously described the synthesis, MMP inhibitory activity, ${ }^{15,16}$ mechanism ${ }^{17,18}$ and metabolism studies ${ }^{19,20}$ of the thiirane-containing compound $\mathbf{1}$, which is a potent (nanomolar) and selective mechanism-based inhibitor of the gelatinases (MMP-2 and MMP-9). This inhibitor is the only mechanism-based inhibitor known for any MMP, and operates by a distinct mechanism that gives rise to stable complex with the gelatinases involving thiolate coordination to the active site zinc atom. Its unique features include a biphenyl moiety that fits into the S1' pocket of these gelatinases, and a thiirane ring that undergoes gelatinase-catalyzed ring opening to give the stable zinc-thiol interaction of the inhibited enzyme (Figure 1). ${ }^{21}$

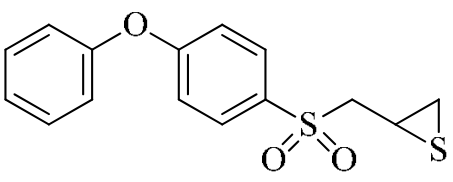

1

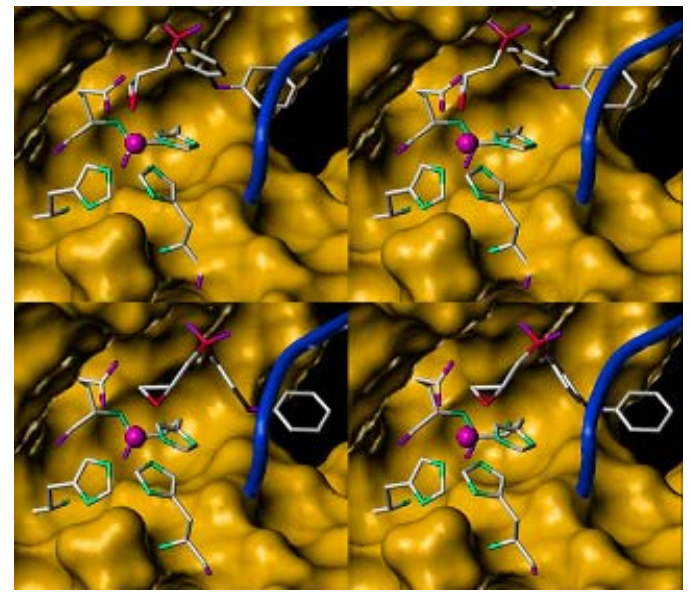

Figure 1. Stereoview representation of compound (R)-1 (top) and (S)-1 (bottom)-both enantiomers are equally active against gelatinases - in the active site of MMP-2. The zinc ion is shown as a purple sphere.

Despite its rapid metabolism in mice ${ }^{20}$ resulting in low systemic concentrations, ${ }^{19}$ as a result of its high potency and the generation of an active metabolite, compound $\mathbf{1}$ is active in vivo in 
several animal models of disease..$^{22,23}$ However, due to its additional liability of poor aqueous solubility, compound $\mathbf{1}$ is precluded from moving forward as a drug candidate. For these reasons, we were interested in the discovery of heteroaryl replacements within the phenoxyphenyl segment to simultaneously impart improved metabolic stability and improved water solubility. Our evaluation of the CuAAC reaction toward this objective is described.

\section{Results and Discussion}

As part of our continuing efforts to explore thiirane-based MMP inhibitors, and with the aim to find an inhibitor with improved pharmacokinetic properties, we used the CuAAC click reaction to rapidly assemble a series of thiirane inhibitors based upon the structure of compound $\mathbf{1}$.

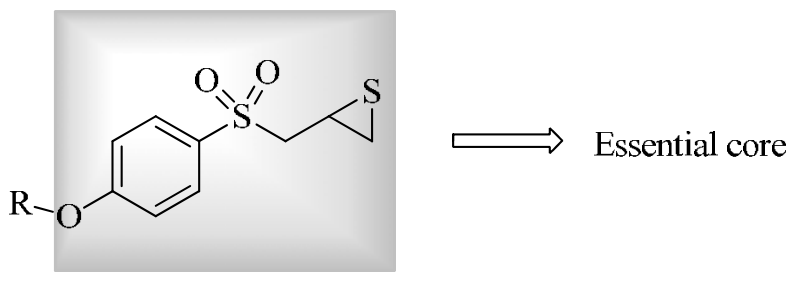

Figure 2

We knew that the core 4-[(thiiran-2-ylmethyl)sulfonyl]phenyl moiety of 1 (Figure 2) was essential to retain the inhibitory activity against gelatinases. Hence, we concentrated on evaluating alternative ring substitutions ( $\mathrm{R}$ of Figure 2) in order to identify a gelatinase inhibitor with improved properties. As MMP-2 has a hydrophobic tunnel-like S1'pocket with an open bottom, the possibility of elongating the molecule by the 1,3-dipolar click cycloaddition to generate a diverse array of triazoles (Scheme 1) was attractive.

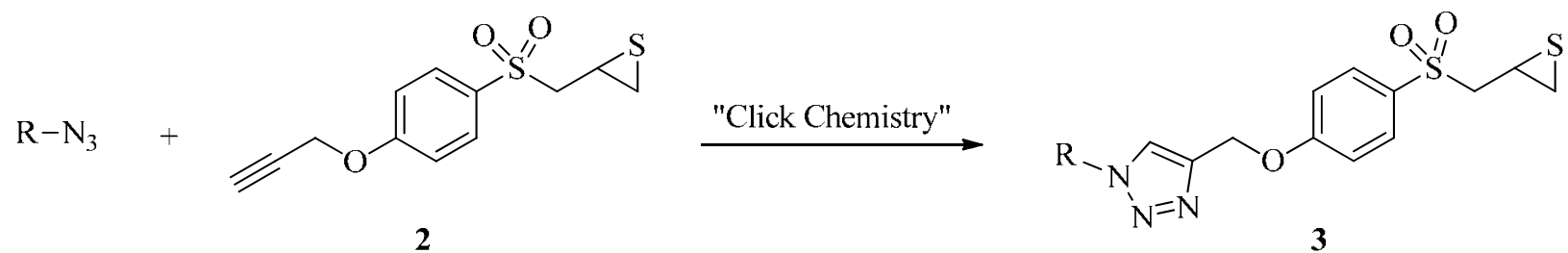

\section{Scheme 1}

The alkyne-thiirane 2 was prepared from 4-hydroxythiophenol 4 as shown in Scheme 2. Selective $S$-alkylation of the commercially available 4-hydroxyphenol 4 with allyl bromide, and subsequent propargylation of the phenol, provided compound $\mathbf{6}$ in high yield. Oxidation of the sulfur and alkene moieties in 6 was achieved with excess $m$-CPBA to afford oxirane $( \pm)-7$ in 
$75 \%$ yield. Conversion of the epoxide to the thiirane ( \pm )-2 was accomplished by thiourea reaction to obtain the desired product in $72 \%$ yield.

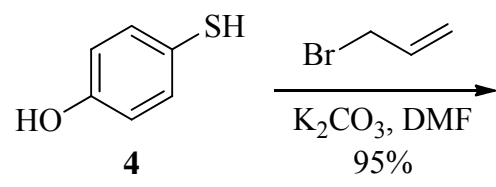<smiles>C=CCSc1ccc(O)cc1</smiles>

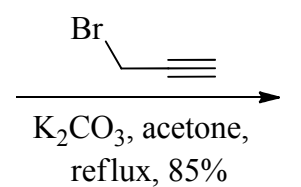<smiles>C#CCOc1ccc(SCC=C)cc1</smiles>

$$
\underset{75 \%}{\stackrel{\mathrm{m}-\mathrm{CPBA}}{\underset{\mathrm{CH}_{2} \mathrm{Cl}_{2}, \mathrm{RT}}{\longrightarrow}}}
$$<smiles>C#CCOc1ccc(S(=O)(=O)CC2CO2)cc1</smiles>

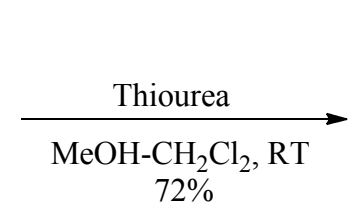<smiles>C#CCOc1ccc(S(=O)(=O)CC2CS2)cc1</smiles>

\section{Scheme 2}

Ten different azides, synthesized using standard azidation methods ${ }^{24}$ and subjected to "click" cycloaddition with alkyne 2 , furnished in high yields the triazolyl-thiiranes 3 (Table 1). We found that a mixed solvent system containing $t-\mathrm{BuOH}$, water and THF $(1: 1: 1)$ dissolved the alkyne and the azides and the reaction mixture proceeded smoothly to completion. The cycloaddition proceeded in a highly regioselective manner, consistent with known literature, ${ }^{6}$ giving only the 1,4-disubstituted 1,2,3 triazole as product.

Table 1. Syntheses of triazole-thiiranes 3

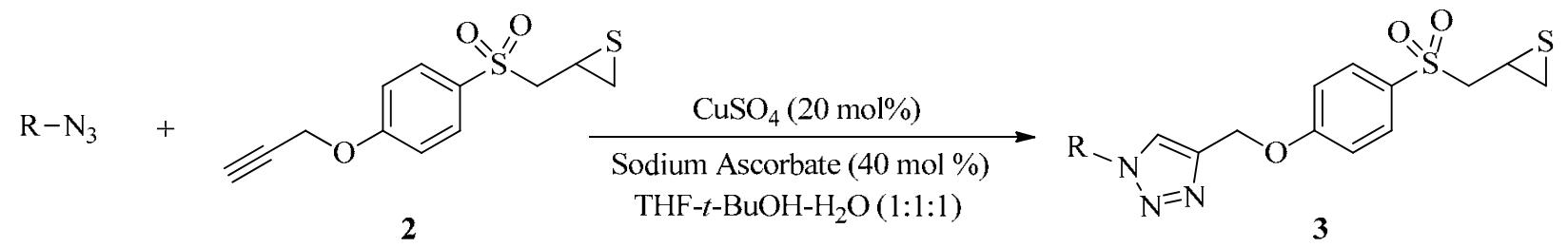

Entry Azide


Table 1. Continued

Entry

${ }^{\mathrm{a}}$ Isolated yields after flash column chromatography.

TACE (TNF- $\alpha$ converting enzyme) is a zinc-dependent metalloproteinase whose active site domain is homologous to that of the MMPs. Potent inhibitors with dual MMP and TACE activity incorporating a butynyloxy tail with a different zinc-binding group (ZBG), were reported previously (Figure 3). ${ }^{25,26}$ Based on this observation, we synthesized the $O$-butynyloxy and $O$-pentynyloxy thiirane analogs for evaluation as gelatinase inhibitors. The synthetic route to these derivatives is depicted in Scheme 3.<smiles>CC#CCOc1ccc(S(=O)(=O)C2CCCC2)cc1</smiles>

\section{Figure 3}


O-Alkylation of phenol 5 with 1-bromo-2-butyne and 1-bromo-2-pentyne gave compounds $\mathbf{8 a}$ and $\mathbf{8 b}$ in high yields, respectively. Subsequent oxidation with $m$-CPBA provided oxiranes $( \pm)-9$ in poor yields, likely reflecting competitive over-oxidation occurring at the internal alkyne. Oxiranes 9a and 9b were treated separately with thiourea to give in good yields the thiiranes $( \pm)$-10a and $( \pm)$-10b. The inhibitory activity against MMP-2 of these thiiranes was evaluated in vitro using a fluorimetric assay in 96-well plate format (Figure 4).

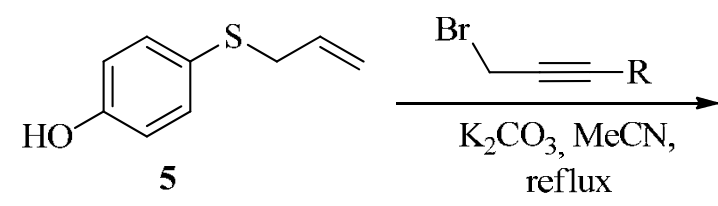<smiles>[R]C#CCOc1ccc(S(=O)(=O)CC2CO2)cc1</smiles><smiles>[R]C#CCOc1ccc(SCC=C)cc1</smiles>

8a: $\mathrm{R}=\mathrm{Me}, 78 \%$

8b: $\mathrm{R}=\mathrm{Et}, 77 \%$

\section{Scheme 3}

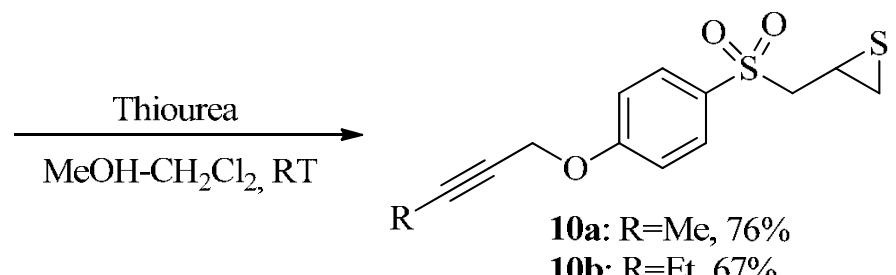

10b: $\mathrm{R}=\mathrm{Et}, 67 \%$

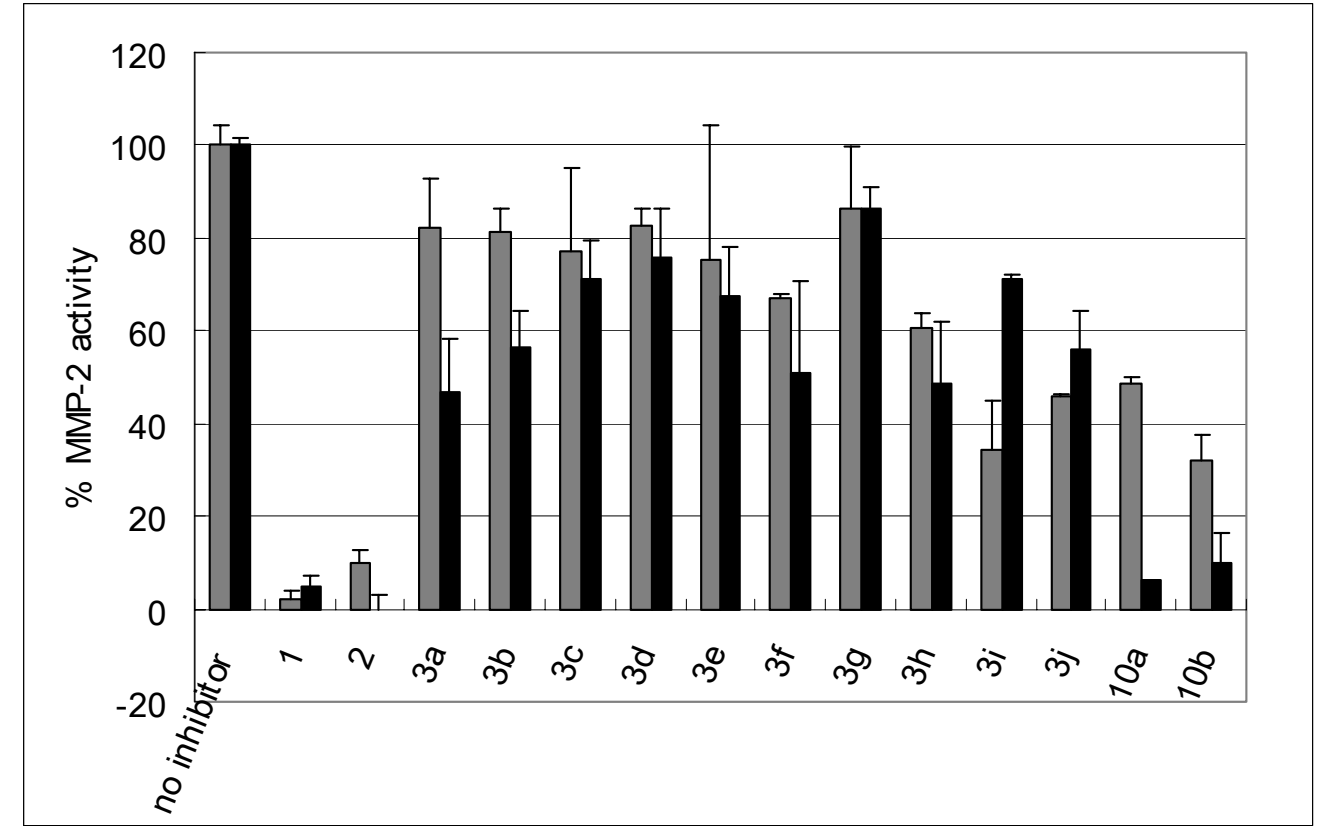

Figure 4. Inhibitory activity against MMP-2 evaluated in vitro using a fluorimetric assay in 96well plate format. The compounds were assayed at $30 \mu \mathrm{M}$ final concentration. The reaction was measured immediately after mixture of the enzyme and inhibitors (grey), and after 3 hour incubation of the enzyme with the inhibitors (black). 
In general, at a concentration of $30 \mu \mathrm{M}$ most of the triazole-thiiranes 3 were poor inhibitors of MMP-2. However, alkynes 2 and 10a, b were good inhibitors of MMP-2, especially following a $3 \mathrm{~h}$ preincubation. Assay of these three alkynes at a lower concentration $(3 \mu \mathrm{M})$, also with a $3 \mathrm{~h}$ preincubation, showed that compounds 2 and 10b gave a $60 \%$ reduction in the activity of MMP2 (Figure 5). Compounds 2 and $\mathbf{1 0 b}$ are less active than compound 1, as evidenced by a 20- and 40 -fold increase in the $\mathrm{IC}_{50}$ values of the respective compounds, compared to compound 1 (Table 2).

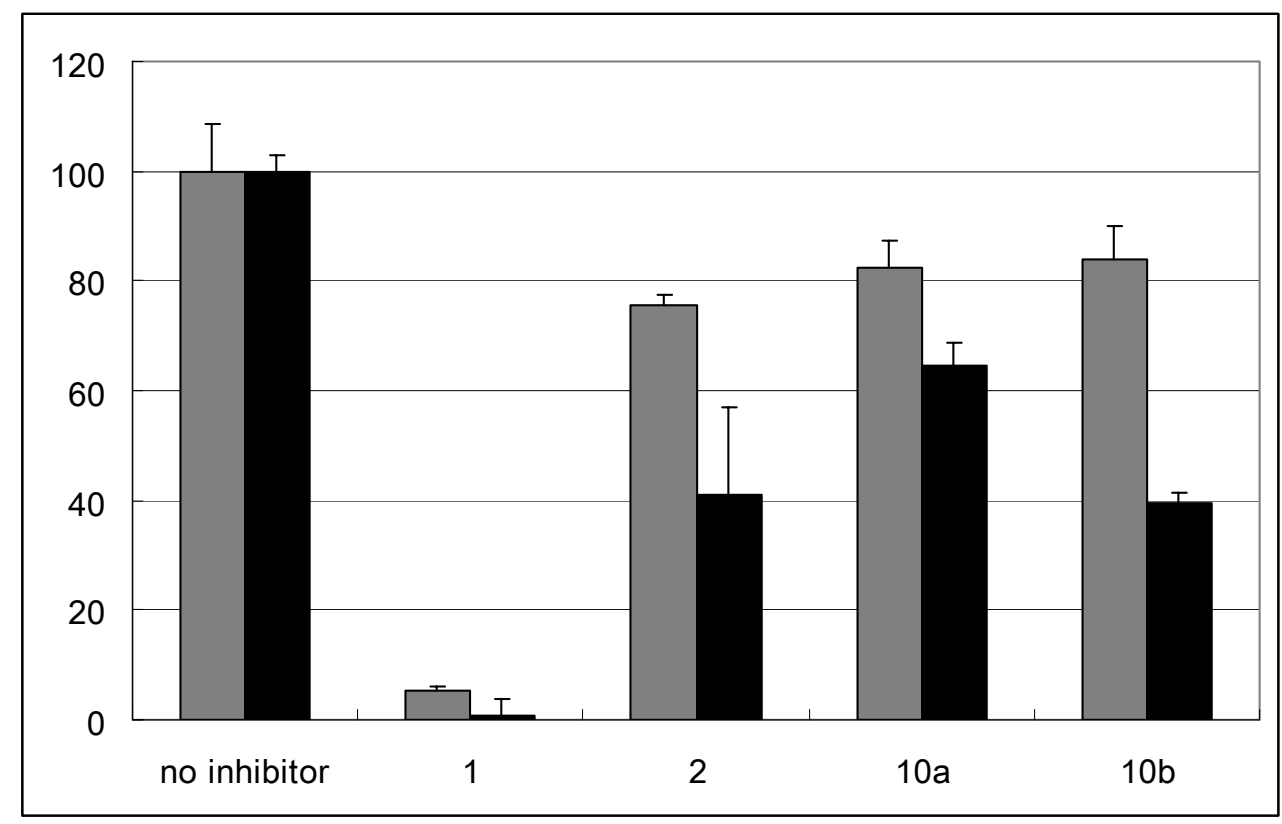

Figure 5. Inhibitory activity against MMP-2 evaluated in vitro using a fluorimetric assay in 96well plate format. The compounds were assayed at $3 \mu \mathrm{M}$ final concentration. The reaction was measured immediately after mixture of the enzyme and inhibitors (grey), and after 3 hour incubation of the enzyme with the inhibitors (black).

Table 2. $\mathrm{IC}_{50}$ of selected thiiranes

\begin{tabular}{cc}
\hline Compound & $\mathrm{IC}_{50}(\mu \mathrm{M})$ \\
\hline $\mathbf{1}$ & $0.4 \pm 0.1$ \\
$\mathbf{2}$ & $7 \pm 2$ \\
$\mathbf{1 0 a}$ & $26 \pm 4$ \\
$\mathbf{1 0 b}$ & $14 \pm 1$ \\
\hline
\end{tabular}




\section{Conclusions}

Excessive catalytic activity by one of the metzincin zinc-dependent proteases (encompassing the MMP and ADAM families) is a characteristic of numerous human diseases. ${ }^{27,28}$ Accordingly, the incorporation of structural segments to attain sub-type selectivity is a focus of every current medicinal chemistry effort directed toward the inhibition of one of these proteases. ${ }^{29,30}$ Toward this objective, the mechanism-based thiirane inhibitor $\mathbf{1}$ is remarkable. It would appear that only members of the gelatinase sub-family of the MMPs (MMP-2 and MMP-9) are able to efficiently use their active site-glutamate for the deprotonation-dependent opening of the thiirane to liberate the caged thiolate as a stable ligand for the catalytic zinc atom. Contributing toward this mechanistic selectivity is the 4-phenoxyphenyl motif of $\mathbf{1}$, an established motif favoring selectivity toward those MMPs with small and hydrophobic S1' pockets (such as MMP-2 and MMP-9). As is characteristic of many structure-activity relationships, however, the selection of a particular substituent reflects compromise. Here, the 4-phenoxyphenyl favorably contributes toward gelatinase selectivity, but imparts unacceptably poor water solubility to the molecule as a whole.

The particular objective of this structure-activity study was the evaluation of triazole replacements for the 4-phenoxy segment, using $\mathrm{Cu}$-catalyzed azide-alkyne cycloaddition to attain structural diversity. While the triazole replacement is certainly more polar than the phenyl that it replaces, we were aware that the gelatinase S1' pocket tolerates well polar substitution at the para-position of this phenyl, ${ }^{31}$ and moreover tolerates well replacement of this same phenyl by small alkyl-substituted sulfonates. Accordingly, recognition of the greater polarity of the triazole was not foreseen as a barrier to the initiation of chemistry. Other possibilities might explain the low activity of the resulting triazole-containing inhibitors against MMP-2. The use of a two-atom $\left(-\mathrm{CH}_{2} \mathrm{O}-\right)$ link between the triazolyl and phenyl rings, arising from the alkynylmethoxy coupling partner in the cycloaddition, is one possible explanation. Triazolylmethyl inhibitors $\mathbf{3 a - 3 \mathbf { j }}$ are better visualized as 4-phenylmethoxy mimetics, rather than 4-phenoxyphenyl mimetics. Within the known structure-activity correlations for MMP-2 inhibition (and also encompassing those for structure 1), the use of the 4-(phenylmethoxy)phenyl as an S1' segment is inferior compared to the 4-phenoxyphenyl.

The second notable structure-activity correlation is the significant MMP-2 inhibitory activity of the 4-alkynylmethoxy derivatives. The 4-alkynylmethoxyphenyl motif has precedent in metzincin protease inhibition design. When paired with many zinc-binding groups, the 4-alkynylmethoxyphenyl motif imparts selectivity towards ADAM protease inhibition, and against MMP inhibition. ${ }^{32-35}$ Nonetheless, in the course of a comprehensive SAR study of the 4alkynylmethoxyphenyl paired to thiol zinc-binding groups, Bandarage et al ${ }^{25,36}$ observed several inhibitors having this pairing that showed both MMP-2 and ADAM-17 inhibitory activity. Our structure-activity data for MMP-2 inhibition are consistent with their data. This structure-activity similarity raises the possibility that the alkynyloxyphenyl-substituted thiirane inhibitors 10a and 10b may exert mechanism-based inhibition within the ADAM metzincin protease family. 


\section{Experimental Section}

General. All organic reagents were purchased from either Sigma-Aldrich Chemical Company (St Louis, MO, USA) or Acros Organics (Geel, Belgium), unless otherwise stated. All reactions were performed under an atmosphere of nitrogen, unless otherwise noted. ${ }^{1} \mathrm{H}$ and ${ }^{13} \mathrm{C}$ NMR spectra were recorded on a Varian UnityPlus 300, or a Varian INOVA-500 spectrometer (Varian Inc., Palo Alto, CA, USA). Chemical shifts ( $\delta)$ are reported using TMS as an internal standard. Reactions were monitored by TLC using $0.20 \mu \mathrm{m}$ E. Merck Silica Gel plates $\left(60 \mathrm{~F}_{254}\right)$ with visualization of product bands by UV fluorescence $(\lambda=254 \mathrm{~nm})$ and/or aqueous cerium sulfate staining, followed by heating. Flash chromatography was carried out with silica gel 60, 230-400 mesh (0.040-0.063 $\mu \mathrm{m}$ particle size) purchased from EM Science (Gibbstown, NJ, USA). Highresolution mass spectra were obtained at the Department of Chemistry and Biochemistry, University of Notre Dame by FAB ionization, using a JEOL AX505HA mass spectrometer or by ESI ionization, using a BRUKER microTOF II mass spectrometer. MMP-2 was purchased from Calbiochem (EMD Chemicals). The fluorogenic substrate (MOCAcPLGL(Dpa)AR- $\mathrm{NH}_{2}$ ) was purchased from Peptides International (Louisville, KY, USA). Substrate hydrolysis was measured with a Varian Cary Eclipse fluorescence spectrophotometer.

\section{Screening of MMP-2 inhibitors on 96-well plates}

Stock solutions of inhibitors $(10 \mathrm{mM}, 1 \mathrm{mM}$, and $100 \mu \mathrm{M})$ were prepared in DMSO. MOCAcPro-Leu-Gly-Leu-A $\mathrm{A}_{2}$ pr(Dnp)-Ala-Arg-NH $\mathrm{N}_{2}$ (Peptide Institute, Inc., Code MOC-3163-v) was reconstituted in DMSO to $1 \mathrm{mM}$ final concentration. The reaction buffer (Buffer R) was $50 \mathrm{mM}$ HEPES pH 7.5, $150 \mathrm{mM} \mathrm{NaCl}, 5 \mathrm{mM} \mathrm{CaCl} 2,0.01 \%$ Brij-35 and 1\% DMSO. The MMP-2 enzyme was diluted in Buffer $\mathrm{R}$ to a final concentration of $2 \mathrm{nM}$. The substrate concentration used in the assay was $10 \mu \mathrm{M}$. Inhibitors were evaluated at concentrations of either $30 \mu \mathrm{M}$ or 3 $\mu \mathrm{M}$. The reaction volume was $200-210 \mu \mathrm{L} .2 \mu \mathrm{L}$ of $1 \mathrm{mM}$ fluorogenic peptide substrate was added to each well of a 96-well black microplate (Greiner bio-one, Cat. \# 655209). In a separate 1-mL 96 well-plate (VWR Cat \# 40002-009) an appropriate volume of the concentrated inhibitor stock was added to each well followed by the addition of $500 \mu \mathrm{L}$ of the $2 \mathrm{nM}$ MMP-2 enzyme stock (e.g. $1.5 \mu \mathrm{L}$ of $10 \mathrm{mM}$ inhibitor stock solution, so as to give a final inhibitor concentration of $30 \mu \mathrm{M})$. The inhibitor solution and enzyme were mixed quickly with a multichannel micropipette $(200 \mu \mathrm{L})$, and $200 \mu \mathrm{L}$ enzyme/inhibitor mixture were transferred to the wells that contained the substrate drops in the 96-well black microplate, and mixed by pipetting up and down. The reaction was measured immediately after mixture of the enzyme and inhibitors, and after approximately $3 \mathrm{~h}$ incubation of the enzyme with the inhibitors. The change in fluorescence intensity in each well (using values for $\lambda_{\text {exc }}=328 \mathrm{~nm}$ and $\lambda_{\mathrm{em}}=393 \mathrm{~nm}$, and $5 \mathrm{~nm}$ excitation and emission slits) was measured over a 15 min interval. The change of the fluorescence intensity with time in the presence of the inhibitors was compared to one observed for the enzyme/DMSO control (slope assigned to $100 \%$ MMP-2 catalytic activity). 
4-(Allylthio)phenol (5). To a stirred solution of 4-hydroxythiophenol 4 (5 g, $39.62 \mathrm{mmol})$ in DMF $(25 \mathrm{~mL})$ at ice-water temperature were added $\mathrm{K}_{2} \mathrm{CO}_{3}(5.5 \mathrm{~g}, 39.6 \mathrm{mmol})$ and allyl bromide ( $3.44 \mathrm{~mL}, 39.6 \mathrm{mmol}$ ). The reaction mixture was stirred for $15 \mathrm{~min}$, and then allowed to warm overnight to room temperature with stirring. After addition of $1 \mathrm{M}$ aqueous $\mathrm{HCl}$, the mixture was extracted twice with EtOAc. The combined organic layers were washed with water and with brine, dried over $\mathrm{Na}_{2} \mathrm{SO}_{4}$, and concentrated under reduced pressure. The residue was purified by silica gel column chromatography (1/10 to $1 / 6$ EtOAc:hexanes) to give $5(6.3 \mathrm{~g}, 95 \%)$ as a white semi-solid. Its ${ }^{1} \mathrm{H}$ and ${ }^{13} \mathrm{C}$ NMR spectra and mass spectrum were identical with reported values. ${ }^{37}$ Allyl[4-(prop-2-ynyloxy)phenyl]sulfane (6). A mixture of the 4-(Allylthio)phenol 5 (2.7 g, 16.4 $\mathrm{mmol}), \mathrm{K}_{2} \mathrm{CO}_{3}(4.6 \mathrm{~g}, 32 \mathrm{mmol})$ and propargyl bromide $(3.6 \mathrm{~g}, 24.7 \mathrm{mmol})$ in dry acetone (30 $\mathrm{mL}$ ) was heated to reflux under nitrogen for $1.5 \mathrm{~h}$. The reaction was concentrated in vacuo giving a yellow oil. The residue was taken in ethyl acetate, washed with water, dried over $\mathrm{Na}_{2} \mathrm{SO}_{4}$, and concentrated under reduced pressure. The resultant residue was purified by silica gel column chromatography to give 6 as a colorless oil $(2.89 \mathrm{~g}, 85 \%)$ : ${ }^{1} \mathrm{H}$ NMR $\left(500 \mathrm{MHz}, \mathrm{CDCl}_{3}\right) \delta 2.52(\mathrm{t}$, $J=2.4 \mathrm{~Hz}, 1 \mathrm{H}), 3.43(\mathrm{dt}, J=7.0,1.1 \mathrm{~Hz}, 2 \mathrm{H}), 4.67(\mathrm{~d}, J=2.5 \mathrm{~Hz}, 2 \mathrm{H}), 4.98-5.04(\mathrm{~m}, 2 \mathrm{H}), 5.84$ (m, 1H), $6.90(\mathrm{~m}, 2 \mathrm{H}), 7.34(\mathrm{~m}, 2 \mathrm{H}) ;{ }^{13} \mathrm{C}$ NMR $\left(125 \mathrm{MHz}, \mathrm{CDCl}_{3}\right) \delta$ 39.0, 55.8, 75.7, 78.3, 115.3, 117.4, 127.1, 133.5, 133.9, 156.9; HRMS (FAB) calcd for $\mathrm{C}_{12} \mathrm{H}_{12} \mathrm{OS}\left(\mathrm{M}^{+}\right)$204.0609, found 204.0600.

( $)$-2-[[4-(Prop-2-ynyloxy)phenylsulfonyl]methyl]oxirane (7). To a stirred solution of the compound 6 (14.55 g, $71 \mathrm{mmol})$ in $\mathrm{CH}_{2} \mathrm{Cl}_{2}(300 \mathrm{~mL})$ was added $m$-CPBA $(63.8 \mathrm{~g}, 284 \mathrm{mmol})$ at ice-water temperature, and the mixture was subsequently stirred at room temperature for 4 days. An additional amount of $m$-CPBA $(16 \mathrm{~g}, 71 \mathrm{mmol})$ was added and stirred for another 4 days. The reaction was filtered and the filtrate was concentrated in vacuo. The residue was taken up in EtOAc and washed sequentially with a saturated $\mathrm{Na}_{2} \mathrm{~S}_{2} \mathrm{O}_{3}$ solution, a saturated $\mathrm{NaHCO}_{3}$ solution, and water. The EtOAc solution was dried over $\mathrm{Na}_{2} \mathrm{SO}_{4}$, and concentrated under reduced pressure. The residue was purified by silica chromatography to give epoxide $7(13.5 \mathrm{~g}, 75 \%)$ as a white solid: ${ }^{1} \mathrm{H}$ NMR $\left(500 \mathrm{MHz}, \mathrm{CDCl}_{3}\right) \delta 2.45(\mathrm{dd}, J=4.7,2.3 \mathrm{~Hz}, 1 \mathrm{H}), 2.58(\mathrm{t}, J=2.4 \mathrm{~Hz}$, $1 \mathrm{H}), 2.81(\mathrm{~m}, 1 \mathrm{H}), 3.23-3.35(\mathrm{~m}, 3 \mathrm{H}), 4.79(\mathrm{~d}, J=2.6 \mathrm{~Hz}, 2 \mathrm{H}), 7.13(\mathrm{~m}, 2 \mathrm{H}), 7.90(\mathrm{~m}, 2 \mathrm{H}) ;{ }^{13} \mathrm{C}$ NMR $\left(125 \mathrm{MHz}, \mathrm{CDCl}_{3}\right) \delta 45.8,56.0,59.5,76.6,77.1,115.3,130.2,131.4,161.7$; HRMS (FAB) calcd for $\mathrm{C}_{12} \mathrm{H}_{12} \mathrm{O}_{4} \mathrm{~S}\left(\mathrm{M}+\mathrm{H}^{+}\right)$253.0535, found 253.0556.

(士)-2-[[4-(Prop-2-ynyloxy)phenylsulfonyl]methyl]thiirane (2). To a stirred solution of epoxide $7(13.5 \mathrm{~g}, 53.5 \mathrm{mmol})$ in $\mathrm{MeOH}-\mathrm{CH}_{2} \mathrm{Cl}_{2}(10: 1,200 \mathrm{~mL})$ was added thiourea $(10 \mathrm{~g}, 133 \mathrm{mmol})$ at room temperature, and the mixture was stirred overnight. After concentration under reduced pressure, the residue partitioned between ethyl acetate and water. The EtOAc layer was separated and washed with brine, dried over $\mathrm{Na}_{2} \mathrm{SO}_{4}$, and concentrated under reduced pressure. The residue was purified by silica chromatography to give thiirane $2(10.26 \mathrm{~g}, 72 \%)$ as a white solid: ${ }^{1} \mathrm{H}$ NMR $\left(500 \mathrm{MHz}, \mathrm{CDCl}_{3}\right) \delta 2.13(\mathrm{dd}, J=4.8,1.8 \mathrm{~Hz}, 1 \mathrm{H}), 2.52(\mathrm{dd}, J=6.2,1.8 \mathrm{~Hz}, 1 \mathrm{H}), 2.59(\mathrm{~d}$, $J=2.2 \mathrm{~Hz}, 1 \mathrm{H}), 3.01-3.19(\mathrm{~m}, 2 \mathrm{H}), 3.53(\mathrm{dd}, J=14.0,5.4 \mathrm{~Hz}, 1 \mathrm{H}), 4.80(\mathrm{~d}, J=2.2 \mathrm{~Hz}, 2 \mathrm{H})$, $7.14(\mathrm{~d}, J=8.8 \mathrm{~Hz}, 2 \mathrm{H}), 7.88(\mathrm{~d}, J=8.8 \mathrm{~Hz}, 2 \mathrm{H}) ;{ }^{13} \mathrm{C} \mathrm{NMR}\left(125 \mathrm{MHz}, \mathrm{CDCl}_{3}\right) \delta 24.2,26.1$, 
56.1, 62.6, 76.7, 77.3, 115.5, 130.5, 130.9, 161.9; HRMS (FAB) calcd for $\mathrm{C}_{12} \mathrm{H}_{12} \mathrm{O}_{3} \mathrm{~S}_{2}\left(\mathrm{M}+\mathrm{H}^{+}\right)$ 269.0306 , found 269.0324 .

The syntheses of the azides of Table 1 used literature precedent. The azides were made from the respective bromides by displacement with sodium azide (Entries $1-7)^{38-40}$ or from the amine by diazo-transfer reaction (Entries 8-10). ${ }^{3}$

\section{General procedure for the syntheses of triazole-thiiranes (3)}

To a solution of thiirane $2(0.149 \mathrm{mmol}, 1$ eq. $)$ and azide $(0.17 \mathrm{mmol}, 1.2 \mathrm{eq})$ in a 1:1:1 mixture of THF $(1 \mathrm{~mL}), \mathrm{H}_{2} \mathrm{O}(1 \mathrm{~mL})$ and $t-\mathrm{BuOH}(1 \mathrm{~mL})$ was added a freshly prepared $\mathrm{CuSO}_{4}$ solution $\left(0.238 \mathrm{~mL}\right.$ of a $0.125 \mathrm{M}$ solution in $\left.\mathrm{H}_{2} \mathrm{O}, 20 \mathrm{~mol} \%\right)$, followed by sodium ascorbate $(0.238 \mathrm{~mL}$ of a $250 \mathrm{mM}$ of freshly prepared solution in $\mathrm{H}_{2} \mathrm{O}, 40 \mathrm{~mol} \%$ ). The reaction mixture was vigorously stirred overnight at room temperature. After completion (monitored by TLC) the reaction mixture was filtered through celite and concentrated in vacuo and the residue was purified by flash column chromatography.

( \pm )-1-Benzyl-4-[[4-(thiiran-2-ylmethylsulfonyl)phenoxy]methyl]-1H-1,2,3-triazole

(3a). Yield 65\%. ${ }^{1} \mathrm{H}$ NMR $\left(500 \mathrm{MHz}, \mathrm{CDCl}_{3}\right) \delta 2.10(\mathrm{dd}, J=5.2,1.8 \mathrm{~Hz}, 1 \mathrm{H}), 2.50(\mathrm{dd}, J=6.2,1.4$ $\mathrm{Hz}, 1 \mathrm{H}), 3.04(\mathrm{dq}, J=7.8,5.6 \mathrm{~Hz}, 1 \mathrm{H}), 3.14(\mathrm{dd}, J=14.3,7.9 \mathrm{~Hz}, 1 \mathrm{H}), 3.50(\mathrm{dd}, J=14.2,5.6$ $\mathrm{Hz}, 1 \mathrm{H}), 5.26(\mathrm{~s}, 2 \mathrm{H}), 5.55(\mathrm{~s}, 2 \mathrm{H}), 7.12(\mathrm{~d}, J=8.8 \mathrm{~Hz}, 2 \mathrm{H}), 7.28(\mathrm{~m}, 2 \mathrm{H}), 7.38(\mathrm{~m}, 3 \mathrm{H}), 7.56(\mathrm{~s}$, $1 \mathrm{H}), 7.84(\mathrm{~d}, J=8.8 \mathrm{~Hz}, 2 \mathrm{H}) ;{ }^{13} \mathrm{C}$ NMR $\left(125 \mathrm{MHz}, \mathrm{CDCl}_{3}\right) \delta 24.2,26.1,56.3,62.2,62.6,115.4$, $122.9,128.1,128.9,129.2,130.6,134.2,143.2,162.6$; HRMS (FAB) calcd for $\mathrm{C}_{19} \mathrm{H}_{19} \mathrm{~N}_{3} \mathrm{O}_{3} \mathrm{~S}_{2}$ $\left(\mathrm{M}+\mathrm{H}^{+}\right)$402.0946, found 402.0936.

( \pm )-1-Phenethyl-4-[[4-(thiiran-2-ylmethylsulfonyl)phenoxy]methyl]-1H-1,2,3-triazole (3b). Yield 82\%. ${ }^{1} \mathrm{H}$ NMR $\left(500 \mathrm{MHz}, \mathrm{CDCl}_{3}\right) \delta 2.12(\mathrm{dd}, J=5.1,1.8 \mathrm{~Hz}, 1 \mathrm{H}), 2.51(\mathrm{dd}, J=6.2,1.8$ $\mathrm{Hz}, 1 \mathrm{H}), 3.05(\mathrm{~m}, 1 \mathrm{H}), 3.12-3.24(\mathrm{~m}, 3 \mathrm{H}), 3.50(\mathrm{dd}, J=14.1,5.5 \mathrm{~Hz}, 1 \mathrm{H}), 4.61$ (t, $J=7.3 \mathrm{~Hz}$, 2H), $5.25(\mathrm{~s}, 2 \mathrm{H}), 7.06-7.13(\mathrm{~m}, 4 \mathrm{H}), 7.25-7.27(\mathrm{~m}, 3 \mathrm{H}), 7.34(\mathrm{~s}, 1 \mathrm{H}), 7.85(\mathrm{~d}, J=8.8 \mathrm{~Hz}, 2 \mathrm{H})$; ${ }^{13} \mathrm{C}$ NMR $\left(125 \mathrm{MHz}, \mathrm{CDCl}_{3}\right) \delta 24.2,26.1,36.6,51.8,62.2,62.6,115.4,123.3,127.2,128.6$, 128.8, 130.6, 136.7, 142.5, 162.6; HRMS (FAB) calcd for $\mathrm{C}_{20} \mathrm{H}_{21} \mathrm{~N}_{3} \mathrm{O}_{3} \mathrm{~S}_{2}\left(\mathrm{M}+\mathrm{H}^{+}\right)$416.1103, found 416.1111 .

( \pm )-1-(3-Phenylpropyl)-4-[[4-(thiiran-2-ylmethylsulfonyl)phenoxy]methyl]-1H-1,2,3-triazole (3c). Yield 67\%. ${ }^{1} \mathrm{H}$ NMR (500 MHz, $\left.\mathrm{CDCl}_{3}\right) \delta 2.10(\mathrm{dd}, J=5.0,1.8 \mathrm{~Hz}, 1 \mathrm{H}), 2.27(\mathrm{~m}, 2 \mathrm{H})$, $2.50(\mathrm{dd}, J=6.2,1.8 \mathrm{~Hz}, 1 \mathrm{H}), 2.66(\mathrm{t}, J=7.5 \mathrm{~Hz}, 2 \mathrm{H}), 3.03(\mathrm{~m}, 1 \mathrm{H}), 3.16(\mathrm{dd}, J=14.2,7.8 \mathrm{~Hz}$, $1 \mathrm{H}), 3.49$ (dd, $J=14.2,5.6 \mathrm{~Hz}, 1 \mathrm{H}), 4.37$ (t, $J=7.2 \mathrm{~Hz}, 2 \mathrm{H}), 5.29$ (s, 2H), 7.14-7.17 (m, 4H), $7.22(\mathrm{~m}, 1 \mathrm{H}), 7.29(\mathrm{~m}, 2 \mathrm{H}), 7.63(\mathrm{~s}, 1 \mathrm{H}), 7.85(\mathrm{~d}, J=8.8 \mathrm{~Hz}, 2 \mathrm{H}) ;{ }^{13} \mathrm{C} \mathrm{NMR}\left(125 \mathrm{MHz}, \mathrm{CDCl}_{3}\right)$ $\delta$ 24.1, 26.1, 31.5, 32.4, 49.6, 62.2, 62.5, 115.3, 122.9, 126.3, 128.3, 128.6, 130.6, 139.9, 142.7, 162.6; HRMS (FAB) calcd for $\mathrm{C}_{21} \mathrm{H}_{23} \mathrm{~N}_{3} \mathrm{O}_{3} \mathrm{~S}_{2}\left(\mathrm{M}+\mathrm{H}^{+}\right)$430.1259, found 430.1257.

( \pm )-6-[4-[[4-(Thiiran-2-ylmethylsulfonyl)phenoxy]methyl]-1H-1,2,3-triazol-1-yl]hexan-1-ol (3d). Yield 74\%. ${ }^{1} \mathrm{H}$ NMR $\left(500 \mathrm{MHz}, \mathrm{CDCl}_{3}\right) \delta 1.25-1.44(\mathrm{~m}, 6 \mathrm{H}), 1.52-1.58(\mathrm{~m}, 2 \mathrm{H}), 1.94(\mathrm{dt}$, $J=14.7,7.3 \mathrm{~Hz}, 2 \mathrm{H}), 2.12(\mathrm{dd}, J=5.0,1.8 \mathrm{~Hz}, 1 \mathrm{H}), 2.52(\mathrm{dd}, J=6.2,1.4 \mathrm{~Hz}, 1 \mathrm{H}), 3.05(\mathrm{~m}$, $1 \mathrm{H}), 3.17(\mathrm{dd}, J=14.3,7.9 \mathrm{~Hz}, 1 \mathrm{H}), 3.51(\mathrm{dd}, J=14.2,5.6 \mathrm{~Hz}, 1 \mathrm{H}), 3.62(\mathrm{t}, J=6.5 \mathrm{~Hz}, 2 \mathrm{H})$, $4.39(\mathrm{t}, J=7.1 \mathrm{~Hz}, 2 \mathrm{H}), 5.31(\mathrm{~s}, 2 \mathrm{H}), 7.16(\mathrm{~d}, J=9.0 \mathrm{~Hz}, 2 \mathrm{H}), 7.63(\mathrm{~s}, 1 \mathrm{H}), 7.86(\mathrm{~d}, J=9.0 \mathrm{~Hz}$, 
$2 \mathrm{H}) ;{ }^{13} \mathrm{C} \mathrm{NMR}\left(125 \mathrm{MHz}, \mathrm{CDCl}_{3}\right) \delta 24.1,25.0,26.0,29.6,30.1,32.2,50.3,62.2,62.3,62.5$, 115.4, 122.9, 130.6, 142.7, 162.6; HRMS (FAB) calcd for $\mathrm{C}_{18} \mathrm{H}_{25} \mathrm{~N}_{3} \mathrm{O}_{4} \mathrm{~S}_{2}\left(\mathrm{M}+\mathrm{H}^{+}\right)$412.1365, found 412.1386 .

( \pm )-4-[4-[[4-(Thiiran-2-ylmethylsulfonyl)phenoxy]methyl]-1H-1,2,3-triazol-1-yl]butan-1-ol (3e). Yield 58\%. ${ }^{1} \mathrm{H}$ NMR (500 MHz, $\left.\mathrm{CDCl}_{3}\right) \delta 1.55-1.60(\mathrm{~m}, 2 \mathrm{H}), 2.00-2.07(\mathrm{~m}, 2 \mathrm{H}), 2.11$ (dd, $J=5.2,1.8 \mathrm{~Hz}, 1 \mathrm{H}), 2.50(\mathrm{dd}, J=6.2,1.8 \mathrm{~Hz}, 1 \mathrm{H}), 3.04(\mathrm{~m}, 1 \mathrm{H}), 3.16(\mathrm{dd}, J=14.2,7.8 \mathrm{~Hz}$, $1 \mathrm{H}), 3.49$ (dd, $J=14.2,5.6 \mathrm{~Hz}, 1 \mathrm{H}), 3.68(\mathrm{t}, J=6.2 \mathrm{~Hz}, 2 \mathrm{H}), 4.43(\mathrm{t}, J=7.2 \mathrm{~Hz}, 2 \mathrm{H}), 5.28$ (s, 2H), $7.14(\mathrm{~d}, J=9.0 \mathrm{~Hz}, 2 \mathrm{H}), 7.67(\mathrm{~s}, 1 \mathrm{H}), 7.84(\mathrm{~d}, J=9.0 \mathrm{~Hz}, 2 \mathrm{H}) ;{ }^{13} \mathrm{C} \mathrm{NMR}(125 \mathrm{MHz}$, $\left.\mathrm{CDCl}_{3}\right) \delta 24.1,26.1,26.9,29.1,50.3,61.8,62.2,62.6,115.4,123.0,130.6,142.8,162.6$; HRMS (FAB) calcd for $\mathrm{C}_{16} \mathrm{H}_{21} \mathrm{~N}_{3} \mathrm{O}_{4} \mathrm{~S}_{2}\left(\mathrm{M}+\mathrm{H}^{+}\right)$384.1052, found 384.1026.

( \pm )-Ethyl 2-[4-[[4-(thiiran-2-ylmethylsulfonyl)phenoxy]methyl]-1H-1,2,3-triazol-1-yl] acetate (3f). Yield 80\%. ${ }^{1} \mathrm{H} \mathrm{NMR}\left(500 \mathrm{MHz}, \mathrm{CDCl}_{3}\right) \delta 1.30(\mathrm{t}, J=7.2 \mathrm{~Hz}, 3 \mathrm{H}), 2.11$ (dd, $J=$ 5.0, $1.7 \mathrm{~Hz}, 1 \mathrm{H}), 2.50(\mathrm{dd}, J=6.0,1.7 \mathrm{~Hz}, 1 \mathrm{H}), 3.03(\mathrm{~m}, 1 \mathrm{H}), 3.14(\mathrm{~m}, 1 \mathrm{H}), 3.51(\mathrm{dd}, J=14.0$, $5.4 \mathrm{~Hz}, 1 \mathrm{H}), 4.27$ (q, $J=7.2 \mathrm{~Hz}, 2 \mathrm{H}), 5.18(\mathrm{~s}, 2 \mathrm{H}), 5.32(\mathrm{~s}, 2 \mathrm{H}), 7.15(\mathrm{~d}, J=8.9 \mathrm{~Hz}, 2 \mathrm{H}), 7.84$ $(\mathrm{m}, 3 \mathrm{H}) ;{ }^{13} \mathrm{C} \mathrm{NMR}\left(125 \mathrm{MHz}, \mathrm{CDCl}_{3}\right) \delta 14.0,24.2,26.1,50.9,62.1,62.5,62.6,115.4,124.5$, 130.6, 143.2, 162.6, 166.1; HRMS (FAB) calcd for $\mathrm{C}_{16} \mathrm{H}_{19} \mathrm{~N}_{3} \mathrm{O}_{5} \mathrm{~S}_{2}\left(\mathrm{M}+\mathrm{H}^{+}\right)$398.0844, found 398.0830 .

( \pm )- $N, N$-Dimethyl-2-[4-[[4-(thiiran-2-ylmethylsulfonyl)phenoxy]methyl]-1H-1,2,3-triazol-1yl]acetamide (3g). Yield 62\%. ${ }^{1} \mathrm{H}$ NMR $\left(500 \mathrm{MHz}, \mathrm{CDCl}_{3}\right) \delta 2.12(\mathrm{dd}, J=5.2,1.8 \mathrm{~Hz}, 1 \mathrm{H})$, $2.51(\mathrm{dd}, J=6.0,1.6 \mathrm{~Hz}, 1 \mathrm{H}), 3.02(\mathrm{~s}, 3 \mathrm{H}), 3.05(\mathrm{~m}, 1 \mathrm{H}), 3.11-3.16(\mathrm{~m}, 1 \mathrm{H}), 3.15(\mathrm{~s}, 3 \mathrm{H}), 3.53$ $(\mathrm{dd}, J=14.2,5.4 \mathrm{~Hz}, 1 \mathrm{H}), 5.26(\mathrm{~s}, 2 \mathrm{H}), 5.32(\mathrm{~s}, 2 \mathrm{H}), 7.16(\mathrm{~d}, J=9.0 \mathrm{~Hz}, 2 \mathrm{H}), 7.86(\mathrm{~m}, 3 \mathrm{H}) ;{ }^{13} \mathrm{C}$ NMR $\left(125 \mathrm{MHz}, \mathrm{CDCl}_{3}\right) \delta 24.2,26.1,34.9,36.7,50.9,62.1,62.6,115.4,125.2,130.6,142.8$, 162.6, 164.7, 169.4; HRMS (FAB) calcd for $\mathrm{C}_{16} \mathrm{H}_{20} \mathrm{~N}_{4} \mathrm{O}_{4} \mathrm{~S}_{2}\left(\mathrm{M}+\mathrm{H}^{+}\right)$397.1004, found 397.1022.

( \pm )-1-(Phenyl)-4-[[4-(thiiran-2-ylmethylsulfonyl)phenoxy]methyl]-1H-1,2,3-triazole (3h). Yield 95\%. ${ }^{1} \mathrm{H}$ NMR $\left(500 \mathrm{MHz}, \mathrm{CDCl}_{3}\right) \delta 2.13(\mathrm{dd}, J=5.2,1.8 \mathrm{~Hz}, 1 \mathrm{H}), 2.52$ (dd, $J=5.8,1.4$ $\mathrm{Hz}, 1 \mathrm{H}), 3.06(\mathrm{~m}, 1 \mathrm{H}), 3.17(\mathrm{dd}, J=14.2,8.0 \mathrm{~Hz}, 1 \mathrm{H}), 3.52(\mathrm{dd}, J=14.2,5.6 \mathrm{~Hz}, 1 \mathrm{H}), 5.40$ (s, 2H), $7.20(\mathrm{~d}, J=8.8 \mathrm{~Hz}, 2 \mathrm{H}), 7.47(\mathrm{~m}, 1 \mathrm{H}), 7.55(\mathrm{~m}, 1 \mathrm{H}), 7.75(\mathrm{~d}, J=8.2 \mathrm{~Hz}, 2 \mathrm{H}), 7.88(\mathrm{~d}, J=$ $9.0 \mathrm{~Hz}, 2 \mathrm{H}), 8.10(\mathrm{~s}, 1 \mathrm{H}) ;{ }^{13} \mathrm{C} \mathrm{NMR}\left(125 \mathrm{MHz}, \mathrm{CDCl}_{3}\right) \delta 24.2,26.1,62.2,62.6,115.4,120.6$, 121.1, 129.1, 129.9, 130.7, 130.8, 143.6, 162.6; HRMS (ESI) calcd for $\mathrm{C}_{18} \mathrm{H}_{17} \mathrm{~N}_{3} \mathrm{O}_{3} \mathrm{~S}_{2}\left(\mathrm{M}+\mathrm{H}^{+}\right)$ 388.0790 , found 388.0787 .

( \pm )-1-(4-Chlorophenyl)-4-[[4-(thiiran-2-ylmethylsulfonyl)phenoxy]methyl]-1H-1,2,3-tri-

azole (3i). Yield 87\%. ${ }^{1} \mathrm{H}$ NMR $\left(500 \mathrm{MHz}, \mathrm{CDCl}_{3}\right) \delta 2.13(\mathrm{dd}, J=5.2,1.6 \mathrm{~Hz}, 1 \mathrm{H}), 2.52$ (dd, $J$ $=6.2,1.8 \mathrm{~Hz}, 1 \mathrm{H}), 3.06(\mathrm{~m}, 1 \mathrm{H}), 3.18(\mathrm{dd}, J=14.2,7.8 \mathrm{~Hz}, 1 \mathrm{H}), 3.50(\mathrm{dd}, J=14.2,5.6 \mathrm{~Hz}, 1 \mathrm{H})$, 5.39 (s, 2H), 7.19 (d, $J=8.8 \mathrm{~Hz}, 2 \mathrm{H}), 7.52$ (d, $J=8.6 \mathrm{~Hz}, 2 \mathrm{H}), 7.71(\mathrm{~d}, J=8.4 \mathrm{~Hz}, 2 \mathrm{H}), 7.88$ (d, $J=8.6 \mathrm{~Hz}, 2 \mathrm{H}), 8.08(\mathrm{~s}, 1 \mathrm{H}) ;{ }^{13} \mathrm{C} \mathrm{NMR}\left(125 \mathrm{MHz}, \mathrm{CDCl}_{3}\right) \delta 24.2,26.1,62.1,62.6,115.4$, $121.1,121.8,130.0,130.7,130.8,134.9,135.2,143.9,162.5$; HRMS (FAB) calcd for $\mathrm{C}_{18} \mathrm{H}_{16} \mathrm{ClN}_{3} \mathrm{O}_{3} \mathrm{~S}_{2}\left(\mathrm{M}+\mathrm{H}^{+}\right) 422.0400$, found 422.0407 .

( \pm )-1-(4-Fluorophenyl)-4-[[4-(thiiran-2-ylmethylsulfonyl)phenoxy]methyl]-1H-1,2,3-triazole (3j). Yield 95\%. ${ }^{1} \mathrm{H}$ NMR $\left(500 \mathrm{MHz}, \mathrm{CDCl}_{3}\right) \delta 2.13(\mathrm{dd}, J=5.2,1.8 \mathrm{~Hz}, 1 \mathrm{H}), 2.52$ (dd, $J=6.0$, $1.4 \mathrm{~Hz}, 1 \mathrm{H}), 3.06(\mathrm{~m}, 1 \mathrm{H}), 3.18(\mathrm{dd}, J=14.2,7.9 \mathrm{~Hz}, 1 \mathrm{H}), 3.51$ (dd, $J=14.2,5.6 \mathrm{~Hz}, 1 \mathrm{H}), 5.39$ 
(s, 2H), 7.18-7.24 (m, 4H), $7.73(\mathrm{~m}, 2 \mathrm{H}), 7.88(\mathrm{~d}, J=8.8 \mathrm{~Hz}, 2 \mathrm{H}), 8.05(\mathrm{~s}, 1 \mathrm{H}) ;{ }^{13} \mathrm{C}$ NMR $(125$ $\left.\mathrm{MHz}, \mathrm{CDCl}_{3}\right) \delta 24.2,26.1,62.1,62.6,115.4,116.7,116.9,121.4,122.6,122.7,130.7,130.7$, 133.0, 143.7, 161.6, 162.5, 163.5; HRMS (FAB) calcd for $\mathrm{C}_{18} \mathrm{H}_{16} \mathrm{FN}_{3} \mathrm{O}_{3} \mathrm{~S}_{2}\left(\mathrm{M}+\mathrm{H}^{+}\right)$406.0695, found 406.0701 .

\section{Allyl-[4-(but-2-ynyloxy)phenyl]sulfane (8a)}

A mixture of 4-(Allylthio)phenol 5 (595 mg, $3.5 \mathrm{mmol}), \mathrm{K}_{2} \mathrm{CO}_{3}(1.0 \mathrm{~g}, 7.1 \mathrm{mmol})$ and 1-Bromo2-butyne $(0.47 \mathrm{~mL}, 5.3 \mathrm{mmol})$ in dry acetonitrile $(30 \mathrm{~mL})$ was heated to reflux under nitrogen for $1.5 \mathrm{~h}$. The reaction was concentrated in vacuo giving a yellow oil. The residue was taken in ethyl acetate, washed with water, dried over $\mathrm{Na}_{2} \mathrm{SO}_{4}$, and concentrated under reduced pressure. The residue was purified by silica gel column chromatography to give 8a as a colorless oil (610 $\mathrm{mg}$, 78\%): ${ }^{1} \mathrm{H}$ NMR (500 MHz, $\left.\mathrm{CDCl}_{3}\right) \delta 1.86(\mathrm{t}, J=2.4 \mathrm{~Hz}, 3 \mathrm{H}), 3.44(\mathrm{dt}, J=7.2,1.1 \mathrm{~Hz}, 2 \mathrm{H}), 4.63$ $(\mathrm{t}, J=2.2 \mathrm{~Hz}, 2 \mathrm{H}), 4.99-5.03(\mathrm{~m}, 2 \mathrm{H}), 5.84(\mathrm{~m}, 1 \mathrm{H}), 6.90(\mathrm{~m}, 2 \mathrm{H}), 7.34(\mathrm{~m}, 2 \mathrm{H}) ;{ }^{13} \mathrm{C}$ NMR $(125$ $\left.\mathrm{MHz}, \mathrm{CDCl}_{3}\right) \delta 3.7,39.1,56.5,73.8,83.9,115.3,117.3,126.6,133.5,133.9,136.0,157.2$; HRMS (FAB) calcd for $\mathrm{C}_{13} \mathrm{H}_{14} \mathrm{OS}\left(\mathrm{M}^{+}\right)$218.0765, found 218.0756.

Allyl-[4-(pent-2-ynyloxy)phenyl]sulfane (8b). Prepared from 5 (603 mg, $3.6 \mathrm{mmol}$ ) as described for 8a, except 1-bromo-2-pentyne substituted 1-bromo-2-butyne in the procedure to afford 650 mg $(77 \%)$ of $8 \mathbf{b}:{ }^{1} \mathrm{H}$ NMR $\left(500 \mathrm{MHz}, \mathrm{CDCl}_{3}\right) \delta 1.13(\mathrm{t}, J=7.5 \mathrm{~Hz}, 3 \mathrm{H}), 2.23$ (qt, $J=7.5,2.1$ $\mathrm{Hz}, 2 \mathrm{H}), 3.44(\mathrm{dt}, J=6.9,1.0 \mathrm{~Hz}, 2 \mathrm{H}), 4.65(\mathrm{t}, J=2.1 \mathrm{~Hz}, 2 \mathrm{H}), 4.98-5.02(\mathrm{~m}, 2 \mathrm{H}), 5.84(\mathrm{~m}, 1 \mathrm{H})$, $6.89(\mathrm{~m}, 2 \mathrm{H}), 7.34(\mathrm{~m}, 2 \mathrm{H}) ;{ }^{13} \mathrm{C} \mathrm{NMR}\left(125 \mathrm{MHz}, \mathrm{CDCl}_{3}\right) \delta 12.5,13.6,39.1,56.5,73.9,89.7$, $115.3,117.3,126.5,133.5,133.9,136.0$, 157.2; HRMS (FAB) calcd for $\mathrm{C}_{14} \mathrm{H}_{16} \mathrm{OS}\left(\mathrm{M}^{+}\right)$ 232.0922, found 232.0939.

(士)-2-[[4-(But-2-ynyloxy)phenylsulfonyl]methyl]oxirane (9a). Prepared from 8a (0.580 mg, $2.65 \mathrm{mmol})$ as described for 7 affording $155 \mathrm{mg}(22 \%)$ of the epoxide 9a as a white solid: ${ }^{1} \mathrm{H}$ $\operatorname{NMR}\left(500 \mathrm{MHz}, \mathrm{CDCl}_{3}\right) \delta 1.87(\mathrm{t}, J=2.3 \mathrm{~Hz}, 3 \mathrm{H}), 2.46(\mathrm{dd}, J=4.8,2.4 \mathrm{~Hz}, 1 \mathrm{H}), 2.81(\mathrm{t}, J=$ $4.3 \mathrm{~Hz}, 1 \mathrm{H}), 3.23-3.36(\mathrm{~m}, 3 \mathrm{H}), 4.74(\mathrm{q}, J=2.3 \mathrm{~Hz}, 2 \mathrm{H}), 7.11(\mathrm{~m}, 2 \mathrm{H}), 7.88(\mathrm{~m}, 2 \mathrm{H}) ;{ }^{13} \mathrm{C}$ NMR $\left(125 \mathrm{MHz}, \mathrm{CDCl}_{3}\right) \delta 3.6,45.9,56.8,59.6,72.7,85.0,115.4,130.2,131.0,162.2$; HRMS (FAB) calcd for $\mathrm{C}_{13} \mathrm{H}_{14} \mathrm{O}_{4} \mathrm{~S}\left(\mathrm{M}+\mathrm{H}^{+}\right)$267.0691, found 267.0671.

( \pm )-2-[[4-(Pent-2-ynyloxy)phenylsulfonyl]methyl]oxirane (9b). Prepared from $\mathbf{8 b}(0.580 \mathrm{mg}$, $2.65 \mathrm{mmol})$ as described for 7 afforded $123 \mathrm{mg}(18 \%)$ of the epoxide $9 \mathbf{b}$ as a white solid: ${ }^{1} \mathrm{H}$ $\operatorname{NMR}\left(500 \mathrm{MHz}, \mathrm{CDCl}_{3}\right) \delta 1.13(\mathrm{t}, J=7.6 \mathrm{~Hz}, 3 \mathrm{H}), 2.23(\mathrm{qt}, J=7.5,2.2 \mathrm{~Hz}, 2 \mathrm{H}), 2.45(\mathrm{dd}, J=$ 4.8, $2.1 \mathrm{~Hz}, 1 \mathrm{H}), 2.80(\mathrm{~m}, 1 \mathrm{H}), 3.20-3.38(\mathrm{~m}, 3 \mathrm{H}), 4.76(\mathrm{t}, J=2.2 \mathrm{~Hz}, 2 \mathrm{H}), 7.11(\mathrm{~d}, J=8.8 \mathrm{~Hz}$, 2H), $7.88(\mathrm{~d}, J=8.8 \mathrm{~Hz}, 2 \mathrm{H}) ;{ }^{13} \mathrm{C}$ NMR $\left(125 \mathrm{MHz}, \mathrm{CDCl}_{3}\right) \delta 12.4,13.5,45.9,56.9,59.6,72.9$, 90.8, 115.5, 130.2, 131.1, 162.2; HRMS (FAB) calcd for $\mathrm{C}_{14} \mathrm{H}_{16} \mathrm{O}_{4} \mathrm{~S}\left(\mathrm{M}+\mathrm{H}^{+}\right)$281.0848, found 281.0833 .

( \pm )-2-[[4-(But-2-ynyloxy)phenylsulfonyl]methyl]thiirane (10a). Prepared from 9a (0.140 g, $0.52 \mathrm{mmol})$ as described for 2 affording $113 \mathrm{mg}(76 \%)$ of the thiirane $10 a$ as a white solid: ${ }^{1} \mathrm{H}$ $\operatorname{NMR}\left(500 \mathrm{MHz}, \mathrm{CDCl}_{3}\right) \delta 1.87(\mathrm{t}, J=2.4 \mathrm{~Hz}, 3 \mathrm{H}), 2.14(\mathrm{dd}, J=5.2,1.8 \mathrm{~Hz}, 1 \mathrm{H}), 2.52(\mathrm{~m}, 1 \mathrm{H})$, $3.06(\mathrm{~m}, 1 \mathrm{H}), 3.15(\mathrm{dd}, J=14.2,8.0 \mathrm{~Hz}, 1 \mathrm{H}), 3.54(\mathrm{dd}, J=14.1,5.7 \mathrm{~Hz}, 1 \mathrm{H}), 4.75(\mathrm{q}, J=2.4$ $\mathrm{Hz}, 2 \mathrm{H}), 7.11(\mathrm{~d}, J=9.0 \mathrm{~Hz}, 2 \mathrm{H}), 7.86(\mathrm{~d}, J=9.0 \mathrm{~Hz}, 2 \mathrm{H}) ;{ }^{13} \mathrm{C} \mathrm{NMR}\left(125 \mathrm{MHz}, \mathrm{CDCl}_{3}\right) \delta 3.6$, 
24.2, 26.1, 56.8, 62.6, 72.7, 85.0, 115.4, 130.4, 130.4, 162.2; HRMS (FAB) calcd for $\mathrm{C}_{13} \mathrm{H}_{14} \mathrm{O}_{3} \mathrm{~S}_{2}$ $\left(\mathrm{M}+\mathrm{H}^{+}\right)$283.0463, found 283.0455.

( \pm )-2-[[4-(Pent-2-ynyloxy)phenylsulfonyl]methyl]thiirane (10b). Prepared from $9 \mathrm{~b}(0.11 \mathrm{~g}$, $0.39 \mathrm{mmol})$ as described for 2 affording $78 \mathrm{mg}(67 \%)$ of the thiirane $\mathbf{1 0 b}$ as a white solid: ${ }^{1} \mathrm{H}$ $\operatorname{NMR}\left(500 \mathrm{MHz}, \mathrm{CDCl}_{3}\right) \delta 1.14(\mathrm{t}, J=7.6 \mathrm{~Hz}, 3 \mathrm{H}), 2.13(\mathrm{dd}, J=5.1,1.7 \mathrm{~Hz}, 1 \mathrm{H}), 2.24(\mathrm{qt}, J=$ 7.5, $2.2 \mathrm{~Hz}, 1 \mathrm{H}), 2.52$ (dd, $J=6.0,1.8 \mathrm{~Hz}, 1 \mathrm{H}), 3.06(\mathrm{~m}, 1 \mathrm{H}), 3.15(\mathrm{dd}, J=14.2,8.0 \mathrm{~Hz}, 1 \mathrm{H}$ ), $3.54(\mathrm{dd}, J=14.2,5.2 \mathrm{~Hz}, 1 \mathrm{H}), 4.77(\mathrm{t}, J=2.2 \mathrm{~Hz}, 2 \mathrm{H}), 7.12(\mathrm{~d}, J=8.8 \mathrm{~Hz}, 2 \mathrm{H}), 7.86(\mathrm{~d}, J=8.8$ $\mathrm{Hz}, 2 \mathrm{H}) ;{ }^{13} \mathrm{C}$ NMR $\left(125 \mathrm{MHz}, \mathrm{CDCl}_{3}\right) \delta 12.4,13.5,24.3,26.1,56.9,62.6,72.9,90.8,115.5$, 130.4, 162.3; HRMS (FAB) calcd for $\mathrm{C}_{14} \mathrm{H}_{16} \mathrm{O}_{3} \mathrm{~S}_{2}\left(\mathrm{M}+\mathrm{H}^{+}\right)$297.0619, found 297.0624.

\section{Acknowledgements}

This research was supported by a grant from the National Institutes of Health. L.I.L. is a Pew Latin American Fellow in the Biomedical Sciences, supported by The Pew Charitable Trusts. The opinions expressed are those of the authors and do not necessarily reflect the views of The Pew Charitable Trusts.

\section{References}

1. Tron, G. C.; Pirali, T.; Billington, R. A.; Canonico, P. L.; Sorba, G.; Genazzani, A. A. Med. Res. Rev. 2008, 28, 278.

2. Moorhouse, A. D; Moses; J. E. Chem. Med. Chem. 2008, 3, 715.

3. Hu, M.; Li, J.; Yao, S. Q. Org. Lett. 2008, 10, 5529.

4. Mamidyala, S. K.; Finn, M. G. Chem. Soc. Rev. 2010, 39, 1252.

5. Rostovtsev, V. V.; Green, L. G.; Fokin, V. V.; Sharpless, K. B.; Angew. Chem., Int. Ed. 2002, 41, 2596.

6. Tornøe, C. W.; Christensen, C.; Meldal, M. J. Org. Chem. 2002, 67, 3057.

7. Huisgen, R.; Guenter, S.; Leander, M. Chem. Ber. 1967, 100, 2494.

8. Huisgen R. In 1,3-Dipolar Cycloaddition Chemistry; Padwa A., Ed.; Wiley: New York, 1984; pp 1-176.

9. Whiting, M.; Muldoon, J.; Lin, Y. C.; Silverman, S. M.; Lindstron, W.; Olson, A. J.; Kolb, H. C.; Finn, M. G.; Sharpless, K. B.; Elder, J. H.; Fokin,V. V. Angew. Chem., Int. Ed. 2006, 45, 1435.

10. Tornøe, C. W.; Sanderson, S. J.; Mottram, J. C.; Coombs, G. H.; Meldal, M. J. Comb. Chem. 2004, 6, 312.

11. Kessenbrock, K.; Plaks, V.; Werb, Z. Cell 2010, 141, 52.

12. Stamenkovic, I. J. Pathol. 2003, 200, 448. 
13. Sternlicht, M. D.; Coussens, L. M.; Vu, T. H.; Werb, Z. In Matrix Metalloproteinase Inhibitors in Cancer Therapy; 2001, p 1.

14. Lee, M.; Fridman, R.; Mobashery, S. Chem. Soc. Rev. 2004, 33, 401.

15. Brown, S.; Bernardo, M. M.; Li, Z. H.; Kotra, L. P.; Tanaka, Y.; Fridman, R.; Mobashery, S. J. Am. Chem. Soc. 2000, 122, 6799.

16. Lee, M.; Bernardo, M. M.; Meroueh, S. O.; Brown, S.; Fridman, R.; Mobashery, S. Org. Lett. 2005, 7, 4463.

17. Forbes, C.; Shi, Q.; Fisher, J. F.; Lee, M.; Hesek, D.; Llarrull, L. I.; Toth, M.; Gossing, M.; Fridman, R.; Mobashery, S. Chem. Biol. Drug Des. 2009, 74, 527.

18. Tao, P.; Fisher, J. F.; Mobashery, S.; Schlegel H. B. Org. Lett. 2009, 11, 2559.

19. Celenza, G.; Villegas-Estrada, A.; Lee, M.; Boggess, B.; Forbes, C.; Wolter, W. R.; Suckow, M. A.; Mobashery, S.; Chang, M. Chem. Biol. Drug Des. 2008, 71, 187.

20. Lee, M.; Villegas-Estrada, A.; Celenza, G.; Boggess, B.; Toth, M.; Kreitinger, G.; Forbes, C.; Fridman, R.; Mobashery, S.; Chang, M. Chem. Biol. Drug Des. 2007, 70, 371.

21. Ikejiri, M.; Bernardo, M. M.; Bonfil, R. D.; Toth, M.; Chang, M.; Fridman, R.; Mobashery, S. J. Biol. Chem. 2005, 280, 33992.

22. Bonfil, R. D.; Sabbota, A.; Nabha, S.; Bernardo, M. M.; Dong, Z.; Meng, H.; Yamamoto, H.; Chinni, S. R.; Lim, I. T.; Chang, M.; Filetti, L. C.; Mobashery, S.; Cher, M. L.; Fridman, R. Int. J. Cancer 2006, 118, 2721.

23. Kruger, A.; Arlt, M. J. E.; Gerg, M.; Kopitz, C.; Bernardo, M. M.; Chang, M.; Mobashery, S.; Fridman, R. Cancer Res. 2005, 65, 3523.

24. Brase, S.; Gil, C.; Knepper, K.; Zimmermann, V. Angew. Chem., Int. Ed. 2005, 44, 5188.

25. Bandarage, U. K.; Wang, T.; Come, J. H.; Perola, E.; Wei, Y.; Rao, B. G. Bioorg. Med. Chem. Lett. 2008, 18, 44.

26. Fisher, J. F.; Mobashery, S. Cancer Metastasis Rev. 2006, 25, 115.

27. Rodriguez, D.; Morrison, C. J.; Overall, C. M. Biochim. Biophys. Acta 2010, 1803, 39.

28. Kessenbrock, K.; Plaks, V.; Werb, Z. Cell 2010, 141, 52.

29. Georgiadis, D.; Yiotakis, A. Bioorg. Med. Chem. 2008, 16, 8781.

30. Dorman, G.; Cseh, S.; Hajdu, I.; Barna, L.; Konya, D.; Kupai, K.; Kovacs, L.; Ferdinandy, P. Drugs 2010, 70, 949.

31. Lee, M.; Celenza, G.; Boggess, B.; Blase, J.; Shi, Q.; Toth, M.; Bernardo, M. M.; Wolter, W. R.; S., M. A.; Hesek, D.; Noll, B. C.; Fridman, R.; Mobashery, S.; Chang, M. Chem. Biol. Drug Des. 2009, 73, 189.

32. Levin, J. I.; Chen, J. M.; Cheung, K.; Cole, D.; Crago, C.; Santos, E. D.; Du, X.; Khafizova, G.; MacEwan, G.; Niu, C.; Salaski, E. J.; Zask, A.; Cummons, T.; Sung, A.; Xu, J.; Zhang, Y.; Xu, W.; Ayral-Kaloustian, S.; Jin, G.; Cowling, R.; Barone, D.; Mohler, K. M.; Black, R. A.; Skotnicki, J. S. Bioorg. Med. Chem. Lett. 2003, 13, 2799.

33. Venkatesan, A. M.; Davis, J. M.; Grosu, G. T.; Baker, J.; Zask, A.; Levin, J. I.; Ellingboe, J.; Skotnicki, J. S.; Dijoseph, J. F.; Sung, A.; Jin, G.; Xu, W.; McCarthy, D. J.; Barone, D. J. Med. Chem. 2004, 47, 6255. 
34. Park, K.; Aplasca, A.; Du, M. T.; Sun, L.; Zhu, Y.; Zhang, Y.; Levin, J. I. Bioorg. Med. Chem. Lett. 2006, 16, 3927.

35. Park, K.; Gopalsamy, A.; Aplasca, A.; Ellingboe, J. W.; Xu, W.; Zhang, Y.; Levin, J. I. Bioorg. Med. Chem. 2009, 17, 3857.

36. Govinda Rao, B.; Bandarage, U. K.; Wang, T.; Come, J. H.; Perola, E.; Wei, Y.; Tian, S. K.; Saunders, J. O. Bioorg. Med. Chem. Lett. 2007, 17, 2250.

37. Goux, C.; Lhoste, P.; Sinou, D. Tetrahedron 1994, 50, 10321.

38. Sá, M. M.; Ramos, M. D.; Fernandes, L. Tetrahedron 2006, 62, 11652.

39. Benati, L.; Bencivenni, G.; Leardini, R.; Minozzi, M.; Nanni, D.; Scialpi, R.; Spagnolo, P.; Zanardi, G. J. Org. Chem. 2006, 71, 5822.

40. Shi, F.; Waldo, J. P.; Chen, Y.; Larock, R. C. Org. Lett. 2008, 10, 2409. 